Sustainable Development and Planning X 247

\title{
ADAPTIVE URBAN TRANSFORMATION: CITIES IN CHANGING HEALTH AND WELLBEING CONDITIONS
}

\author{
ELŻBIETA D. RYŃSKA \& KRYSTYNA SOLAREK \\ Faculty of Architecture, Warsaw University of Technology, Poland
}

\begin{abstract}
Current spontaneous development is particularly characteristic to the urban areas of the Southern, Eastern and Central parts of Europe where the urban structure has historically been very compact, but in the past few decades have started to grow rapidly outward. Therefore, it is apparent that new policies and tools are necessary to control urban transformations. This paper is dedicated to research based on the modern approach to the application of an urban idea introduced first in Warsaw's development plans in the beginning of the 20th Century. Research is presented on the canvas of a concept dedicated to the improvement and redefinition of cities that have appeared for the past hundred years and today are undergoing transformation. This study briefs on chosen development plans of Warsaw. Research is based on the first modern plans for Warsaw, presented in the beginning of the 20th Century. These ideas were unified with the aim to propose a model urban development of Warsaw, which would allow achievement of a possible best air parameters within city limits achieved through a connection with surrounding urban region. Described concept of a city air exchange system, forgotten for many years, now due to high air pollution within urbanized areas, has appeared again as a more modern approach and is presently beginning to be used as one of the city management tools. The result of this study is to propose a new approach to the spatial structure transformation of Warsaw, based on the historically established ideas but better suited to the current conditions, and in the same time guaranteeing the proper flow and circulation of air in the city.
\end{abstract}

Keywords: urban transformation, spatial structure, adaptation to climate change, Warsaw, development plan, air circulation.

\section{INTRODUCTION}

The link between the Warsaw urban development and the city's climate has never been sufficiently recognized as part of a scientific research. Hence, development of the Polish capital, although this relationship has been taken into account for over 100 years, never truly followed environmental conditions. The first modern urban transformation plans of the city were drawn up with reference to the European and world trends, which from the turn of the $20^{\text {th }}$ Century began to place the quality of life in the cities as one of the leading aims.

As part of the main environmental parameters, climatic conditions play a major role in the function of ecosystems. In the urbanized areas, they have a high influence on the city functions due to interactions with existing infrastructure, land developments and city ecosystems. Only to undergo further interaction, as intensive urban tissue, street network system, location of large malls and industrial areas also have impact on the local environmental and climatic conditions. There are several EU documents which can be identified as support tools for any actions. The most important state intelligent development based on the knowledge and innovation, sustainable development as well as social participation allowing for cohesive social and territorial high standard development [1]. This is further supported through EU Territorial Agenda [2], which point out main aims which should be sough and developed independently by the cities, amongst other issues there is a statement that management and development of connections between ecologic, landscape and cultural systems is one of the priorities. 
In general, it must be pointed out that whatever measures might be undertaken they must be based on the fact that since mid- $20^{\text {th }}$ Century the main perceived process is rise of the global temperatures both within the troposphere as well as in the oceans. Hence, the outcomes will be visible in many different places. Future changes are subject to numeric modelling starting from very simple once and down to ESM-Earth System Models [3]. The scenarios show that depending on the global rise of temperatures, the heat extremes will also become part of our daily lives.

For Poland, the climate changing scenarios have been prepared by researchers working in KLIMADA project [4]. These based on 8 regional models and 4 global ones and the scenarios were prepared based on the outcomes UE ENSEMBLES project. The outcomes show that by the ned of 2090, average annual temperature in Poland will rise by $3^{\circ} \mathrm{C}$, the number of extreme heat days (over $25^{\circ} \mathrm{C}$ ) will double, and more than 250 will reach temperatures above $5^{\circ} \mathrm{C}$. Precipitation values will also change, especially in case of circadian cycle with $30 \%$ higher rainfall. The number of days with snow coverage will not exceed more than 40 days.

Additional scenarios were provided also for Warsaw [5]. The outcomes of the analysis show that annual average temperature in Warsaw will be between 10 to $12^{\circ} \mathrm{C}$ (temperature will rise by $0.5^{\circ} \mathrm{C}$ each year). This in turn will be mirrored with longer heat waves (even over $30^{\circ} \mathrm{C}$ ), lower quality of air parameters, intensive UHI effects. Hence, city adaptation to changing climate should include user friendly city infrastructure including use of existing natural resources.

\section{NEW-OLD CONCEPTS FOR SHAPING A HEALTHY URBAN ENVIRONMENT}

The beginnings of comprehensive shaping of healthy urban environments date back to the second phase of the Industrial Revolution, when the low quality of living conditions associated with the development of industrial cities reached a critical point. This was met with the development of scientific research, which simultaneously combined with new transport means and energy options led to thinking about innovative prescriptions for improving living conditions in the cities. Numerous new concepts of city transformations which date back to the turn of the $20^{\text {th }}$ Century were a reaction to the growing problems related to the development of industrial cities [6].

Although, since the Renaissance, many theoreticians dealing with urban areas have paid attention to the necessity of subordinating the city concept to the needs of inhabitants and creating a healthy environment, it was only as a result of the growing sanitary problems that these ideas were implemented in Industrial Era. At first, at the turn of the $19^{\text {th }}$ Century, the concept of urban green zones changed significantly. Increasingly, as new solutions appeared green areas in various forms and with different functions ceased being used only for decoration purposes. The health of people became an important reason for establishing public gardens - initially for defined social groups, later for all city inhabitants. In the $19^{\text {th }}$ Century, although private gardens were still being built, an important argument for establishing public ones was to improve the living conditions for the city residents.

The newer concepts of the mid- $19^{\text {th }}$ Century emphasized the need to ensure good air circulation and high standard of the air parameters. Interesting were the concepts with the main motive of creating a city that would function like a living organism, and thus should be equipped with counterparts of the bloodstream and respiratory system. Architects "wanted to create a city where one could move and breathe freely, a city made of arteries and veins that carried a flow of people like healthy blood cells" [7, p. 206]. Urban projects were created, according to this concept. The creators wanted to facilitate the movement of people in the city, and "people flowing through the streets - arteries would circulate around the green areas and breathe the fresh air - just as the blood refreshes the lungs" [7, p. 260]. In many cities 
around the world, parks began to play the role of "urban lungs" rather than spiritual as was the case in medieval gardens. Broad communication arteries, including green boulevards in rebuilt Paris, or park systems in the place of the former Vienna fortifications, huge parks in the centre of Helsinki and New York or green zones inside the quarters set out by Ildefonso Cerda in Barcelona, are still the evidence of changes in the way of thinking about city structure.

Worth noting is the feedback of the urban trends of the mid-19th Century Europe and North America. In 1829 John Claudius Loudon, a Scottish landscape architect who also considered himself an urbanist, published a book "Hints for Breathing Places for Metropolis", in which he presented a vision of London's land development plan based on the concept of green rings. He wrote many articles and guides on green area planning. Activities of the American landscape architect Andrew Jackson Downing and his students Frederick Law Olmsted and Charles Elliot were clearly under the influence of these studies, In the US, the response to the growing problems of industrial cities was the emergence and development of land domains, their creation expressed in various reforms of the late $19^{\text {th }}$ Century, such as "Parks movement" or "City Beautiful movement" [8]. Olmsted is considered the main advocate of these ideas. It is worth noting that the way of thinking about shaping the city green areas was probably influenced by his journey to Europe, which took place in the mid$19^{\text {th }}$ Century. Ebenezer Howard, after studying in the USA and learning about the projects designed by Olmsted, created the concept of a city garden. This groundbreaking idea contributed to the spread of the vision of a place of residence surrounded by nature and located in a high-quality environment. This idea affected the urban transformation of many centers.

The beginning of the 20th Century brought the explosion of international modernism including the new solutions shaping vast urban tissue systems, with the main aim to improve the cities and the living conditions of inhabitants. One of the key issues was the approach to the city landscape that would ensure the best living conditions. Of course, the scope of these improvements was adequate to the current needs, priorities and state of knowledge mainly focused on provision of daylight, open spaces and access to green areas. From the beginning of the 20th Century the main feature of many urban plans was the division of the city into functional zones, location of the wedge-like urban green area, and often dispersed peripheral housing estates. This idea is very clearly highlighted in the model conceptual plan for the expansion of Berlin. Max Berg proposed the development of the city in a belt system, separated by urban green zones, whereby various types of green areas also reduced intensity in chosen urbanized zones [9].

A quarter of a century later also part of the post-war plan for the reconstruction of London and its region, developed by Patrick Abercrombie (1944) showed a differently shaped system of green, constituting a barrier protecting the outskirts of cities against the uncontrolled outflow of urbanization. This zoning plan, based on a communication system with radial and bypass arteries, provided for the creation of a green ring, the so-called "Green belt" around developed areas. This assumption was adopted as a pattern for similar studies around the world.

The modern movement has strengthened the tendency to treat green areas as an element improving the living conditions in the city and surroundings. Many green towns and settlements were created based on this idea. However, since the 1960's and 1970's, various negative effects of the implementation of cities according to the principles of functionalism have been increasingly criticized. Urban development projects started to emphasize the importance of links between new building complexes and the traditional urban fabric. Pedestrian traffic and the use of traditional forms urban planning became the preference. At 
that time, the issues of planned green systems and other open areas as well as the cities' resilience to unfavorable climatic and environmental conditions were considered secondary.

Today, after years of criticism of modernism and the search for new urban concepts, the view has clearly crystallized that one of the most important challenges in transforming urban structures is finding solutions that ensure the safety and convenience of urban residents and protection against various negative phenomena. This does not change the approach that promotes compact, economical, inclusive cities. However, it becomes crucial to enable cities to adapt to the climate change through the appropriate shaping of their building structure.

In many Polish cities, including Warsaw, low emissions are a serious threat, requiring different actions, including urban transformations. These emissions can be reduced by improving the air inflow conditions, regeneration of air channels and air exchange in the city. Adequate distribution of the open areas, including green ones in the structure of the city will positively affect the comfort of living and will reduce the risk that results from the climate change. In particular, the intensification of adverse smog phenomena and the heat island effect.

\section{PLANNING THE SPATIAL STRUCTURE OF WARSAW FOR CREATING HEALTHY LIVING CONDITIONS FOR THE RESIDENTS}

In response to the world-wide spread of the garden-city idea and the healthy cities concept, a comprehensive concept of new locations for settlement complexes around Warsaw was presented already in 1911 by Alfons E. Gravier. In this scheme Warsaw and the surrounding area was developed as a ring of buildings separated from the central districts of Warsaw by a rural zone, called the "first strip of suburban colonies". This vision, however, did not have its continuation in later planning work [10].

In 1916, under the German occupation, at the initiative of the Temporary City Council, the Warsaw city's borders were extended, absorbing low developed suburbs, and tripling the surface area [11]. The team headed by T. Tołwiński for the first time developed the land layout of the city called: "Preliminary Sketch of the Regulatory Plan of the Capital City of Warsaw". This plan was aimed not only at defining the city's development principles, but also took into account newly joined districts. It also included the issue of air's purity level in the densely compact, pre-war Warsaw centre development. One of the plan drawings shows the layout of parks and green zones. In accordance with the guidelines of the Warsaw authorities "Sanitary and health issues of the city" were included. Also, in accordance with the global urban trends of those times, particular attention was paid to the issue of shaping of the urban green system. It is possible to distinguish a planned system, because as far as possible, individual parks, gardens and greenhouses were connected with smaller areas of green including avenues and with agricultural areas on the outskirts of the city. In the description of the plan, the most important areas were named "green wedges". A particularly large undeveloped area was provided in the Vistula River valley. Already at that time, the city was divided into a concentrated area of a compact city centre, and a fairly fragmented layout of the buildings on the outskirts, separated by vast undeveloped zones.

In the assumptions for the next General Plan of Warsaw, prepared for the exhibition held in Poznań in 1928 by the team led by Stanislaw Różański, the vision of the radial-band structure of the capital and its surroundings was consistently maintained. In that year the first concept of air infiltration wedges drawing clean air into Warsaw centre has also already appeared. "Due to hygienic reasons, urban organism, was torn by parks, cemeteries, reserves, etc., concentrated into wedges" [12]. 

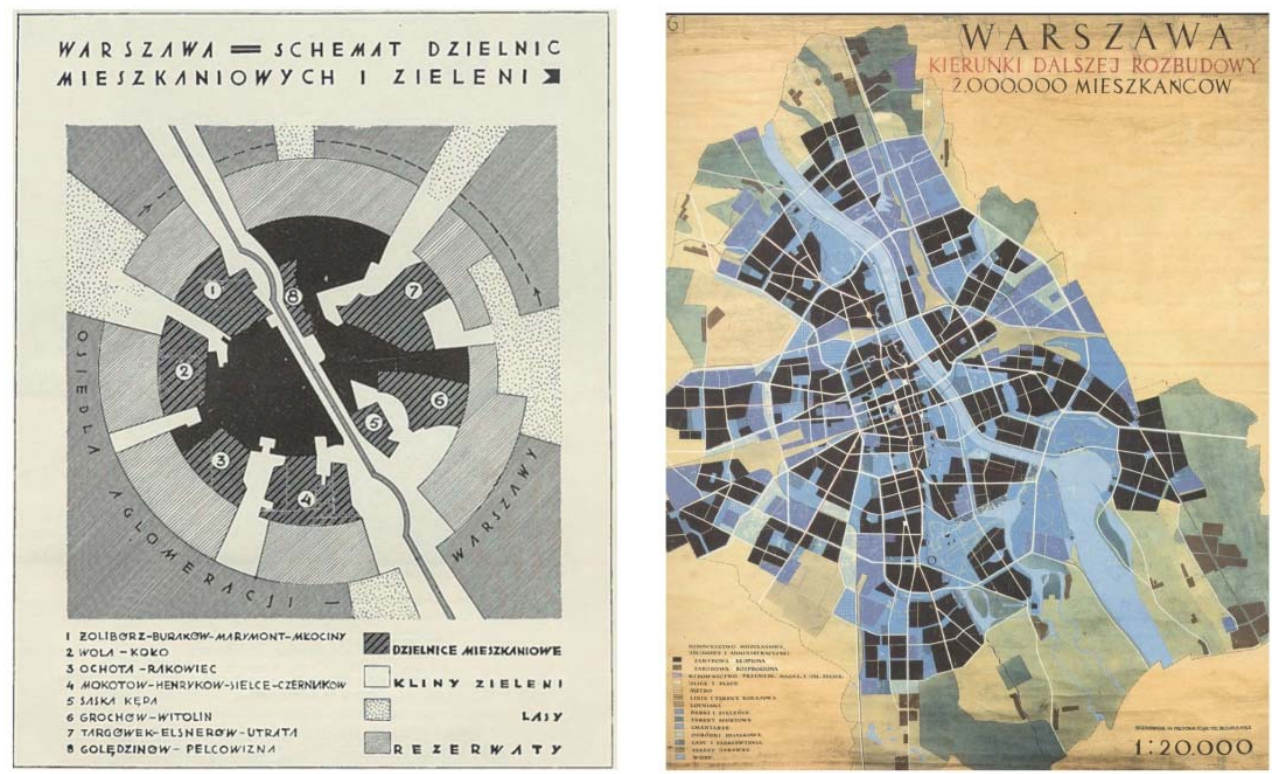

Figure 1: The belt-and-radial settlement system of Warsaw and its surroundings. Left: Diagram of residential districts and green areas, 1931. (Source: [18].) Right: General Plan of Warsaw. Directions for further expansion, 1954. (Source: [15].)

The concept of a healthy urban environment has been generally accepted, supplemented and developed over many decades. The open areas wedge system, adopted in the general plan of Warsaw's buildings from 1931, designed by S. Różański, became the base for the arrangement of air corridors in later planning studies (up to modern times). This plan was a first legally binding document for Warsaw, it belonged to the avant-garde of urban planning, and in later years it initiated the idea of the belt-and-radial settlement system of Warsaw and its surroundings (Fig. 1). The Różański Plan was adopted by the City Council in April 1930 and approved in 1931 by the Ministry of Public Works as a General Plan of the Capital City of Warsaw. Warsaw, and then became for many years the only basis of the capital's local law (co-authors: M. Buchiewiczówna, J. Reński and J. Graefe). It was continued by i.e. unapproved plan for the development of Warsaw in 1937-1938.

The concept of the belt-node system of the capital together with its surroundings has been reflected in studies for the Warsaw agglomeration and related study concepts. In the years 1932-1933, Jan O. Chmielewski created the concept of Warsaw as a vast settlement complex planned in accordance with the principles of modern urban planning at the Warsaw Regional Plan Office. It was at that time a pioneering approach, and the project, developed with Szymon Syrkus, known as "Functional Warsaw", was appreciated in 1934 at the International Congress of Modern Architecture (CIAM) and recommended to be propagated as a model concept of a rational city structure and a model example of urban development. The essence of the concept presented at that time was the principle of functional de-concentration of the city and polarization of its development in areas of varying intensity. The project presented a vision of a "green city" - clear, hygienic, ensuring access to green for all residents, opposing the prevailing concept of: tight, compact, and unhygienic. It was based on many large-scale 
studies and their outcomes also indicating directions of development. Its most characteristic element was the formation of settlement complexes in a form of "functionalized belts", distinguished from the background of "urbanistic passive areas" [13]. This idea promoted a novel concept of a functional urban region. It was a threshold for the development of new regional planning with a vision for the Warsaw's future development based on functional and air inflow strips intersecting the city's core in order to provide high standard living.

The ideas of the modern movement were highly appreciated in Warsaw when it required reconstruction after almost complete destruction and depopulation at the end of the Second World War (1945). This contributed to the adoption of plans, providing low intensive developments separated by extensive green areas and interconnected by multi-lane roads. Such a layout was initially planned for the city development concept dating from 1945, and later in the Warsaw Reconstruction Plan of 1946. Open spaces were structuralizing the city space and, what is interesting; their area exceeded the footprint of built-up areas. However, they did not create distinct wedges, but rather a grid of broad North-South stripes and narrow inlets on the East-West line, surrounded by a green ring. The green ring zone also separated downtown from residential districts.

From circa 1948, simultaneously with the propagation of the concept of a compact city better suited to the idea of realism, the ideas guiding the concept of J. Fr. Chmielewski were abandoned, describing it pejoratively as a "de-urbanization trend". In 1949, regional planning was thus formally abandoned for a dozen or so years and plans for Warsaw began to be prepared within administrative borders. In 1950 and 1951, informal concepts of the plan of Great Warsaw were created in the Warsaw Urban Office (WZM), extending between Młociny, Natolin, Ząbki and Ursus [14]. The links between the capital and the surrounding areas were noticed, and visions of the WZM prospective plan were created. It was considered that the influence of Warsaw exceeds the distance of $20 \mathrm{~km}$ from the centre, and satellite towns outside of the area of Great Warsaw require a radical expansion which included transfer of industrial plants. The area encompassing these towns was included in the suburban area, forming together Great Warsaw Area.

In the following years, attempts were made to make the city structure more cohesive, although - as a result - these were not successful attempts, as building areas increasingly penetrated the outskirts of Warsaw. At that time, both directional and staged plans were prepared, including "Six-Year Reconstruction Plan for Warsaw" from 1949-1955, "FiveYear Plan for the Construction of Warsaw" from 1956-1960, General Plan of Warsaw (19601980) [15].The extensive and numerous green areas were still pointed out as important, although the legibility of the open areas was blurred. Due to the location conditions, the most distinctive corridor of green areas was the Vistula River valley and the undeveloped outskirts of the city. The site plans indicated free standing buildings surrounded by green areas. Hence, in connection with these regulations and the policy of locating buildings outside the city, the choice guaranteed the preservation of favourable climatic conditions, which was also supported by the low level of individual; vehicles.

After many changes, this concept developed in 1992 into the "Air Exchange and Regeneration System", adopted in the General Plan of Spatial Development of the Capital City of Warsaw.

The current document is the Study of conditions and directions of spatial development of the Capital City of Warsaw, made, among others on the basis of the "Eco-physiographic Study for the Study of Conditions and Directions of Spatial Development M. Warsaw" from 2006. Currently, the Study of conditions and directions of spatial development in Warsaw indicate the so-called areas of air exchange corridors, highlighted within the basic and supporting areas of the Warsaw Nature System, which are: the Vistula corridor, the 
underpass, the Mokotow corridor, corridor of Aleje Jerozolimskie, Western Railway Corridor, Bemowski Corridor, North Railway Corridor, Eastern Railway Corridor (Fig. 2). The following development rules are established in the areas of air exchange corridors: prohibition to locate any equipment and installations that may adversely affect air quality, prohibition to locate buildings restricting free movement of air masses, - the obligation to develop the area in a manner supporting conducive to air exchange, - development of areas on the conditions specified in the Study. Master Plans cover only 25-30\%, therefore most of the new developments is constructed based on the Conditions of Land Development issued separately to interested investors often with content not corresponding to the land planning policy of the city. Thus, several wedges have been "mutilated" and the way they function must be reconsidered. This example, however, shows how important it is to consistently build urban air exchange systems - from the level of planning them in the study of conditions and directions of land development and based on interdisciplinary research which should be included and adapted in local zoning plans [16].

In view of many rapid changes taking place within the development of Warsaw, the City Government requested a thorough analysis checking the potential to shape climatic conditions [17].

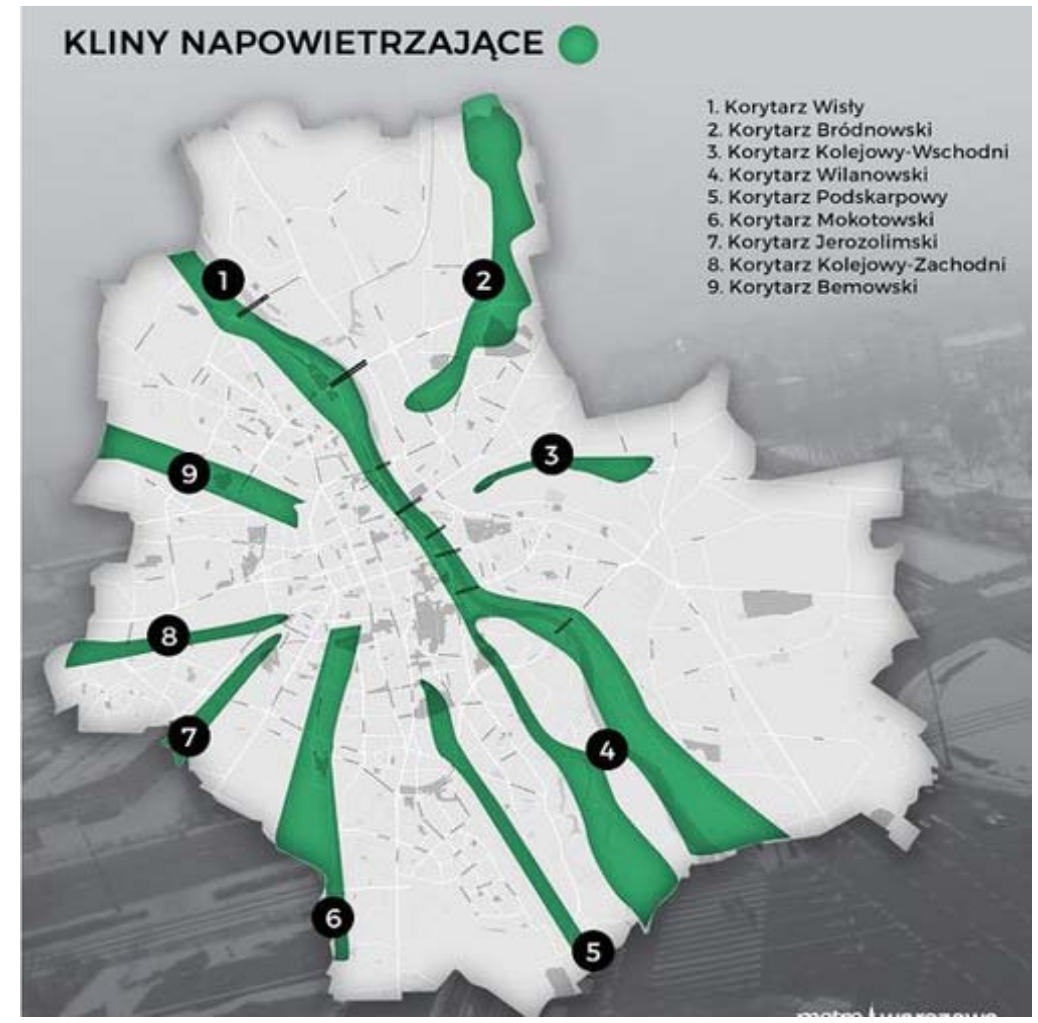

Figure 2: Contemporary air exchange system in Warsaw - schematic drawing 1. Vistula River Corridor 2. Brodno Corridor 3. East-Train Corridor 4. Wilanow Corridor 5. Under-Embankment Corridor 6. Mokotow Corridor 7. Jerozolimski Corridor 8. West-Train Corridor 9. Bemowo Corridor. (Source: [19].) 
Analysis was made in order to establish potential to shape climatic conditions, with an aim to allow for natural air exchange and regeneration of air standards in order to achieve a better quality of the residents' health and wellbeing conditions. Analysis included specific Warsaw climatic parameters including climatic background conditions such as the number of solar hours, thermal conditions, anemology, humidity, precipitation and pollution parameters - as the major ones having influence on the health and wellbeing conditions. Characteristic local parameters were set forth for the Warsaw area. These included urban heat islands (UHI), wind movements in the city based on a 3D numeric model with special attention to two chosen air corridors and based on the changes in the development which took place between 2008 and 2015. Fluctuations in the air quality (i.e. $\mathrm{PM}_{10}, \mathrm{PM}_{2.5}$, nitrogen dioxide and ozone) were also analysed as 3D models. Model allowed description of anemology conditions measuring average wind speed at $4 \mathrm{~m}, 10 \mathrm{~m}$ and $15 \mathrm{~m}$ above the ground level.

This intricate analysis allowed the consortium (with special input from The Institute of Meteorology and Water Development) to prepare an air valuation map of Warsaw, showing three classes distinguished based on the wind speed criteria. Good air flow conditions were accepted as exceeding $4 \mathrm{~m} / \mathrm{s}$ when measured at $10 \mathrm{~m}$ above the ground level. Used methodology allowed specifying a yearly air quality index which included existence of three types of pollutions ( $\mathrm{MP}_{10}, \mathrm{MP}_{2.5}$ and nitrogen dioxide). Further analysis allowed defining a relationship between the level of air exchange and the quality of air within the city. This analysis was used in a numerical calculation matrix with the outcomes proposing resignation from the contemporary definition of "air corridors and regeneration zones". New definitions indicate the requirement to delimit following areas:

1. air movement areas - delimited based on the air valuation class and frequency of UHI; these areas cover the existing air corridors and regeneration zones

2. air regeneration areas - delimited based on the air and sanitary conditions (at least good and very good parameters)

3. intensive air regeneration zones - which exists within the air regeneration areas, but have high humidity values as well as intensive green land coverage

The main regeneration areas are green and small rural zones located off North-West and South-East. From the point of view of the anemology specialists, dense foliage appears to hinder the air infiltration process, but at the same time are the sources of air regeneration (humidity and lower temperatures). Hence, areas which should be used for air movement purposes should not be densely covered with trees and plants, this is opposite to the parameters required by the air regeneration areas. I case of intensive urban development, high trees can influence vertical movement of air currents, as in such areas usually being UHI circulation should be initiated based on thermal exchange.

A lot of attention is paid to the relevance of Master Plans (currently only circa $35-40 \%$ of Warsaw area is subjected to MP conditions), where proposed building line should be shaped in such a way as to force natural ventilation process.

\section{SUMMARY}

In many urban development concepts, climatic issues were taken into account as one of the key factors influencing the formation of man-made structures from the beginning of the $20^{\text {th }}$ Century, as previously discussed. Not all of the planned areas were explicitly referred to as "air inflow areas", although in reality they were always established to play an important role in shaping of the natural structure of the city and treated the "sensitive" area responsible for shaping the features of the urban bioclimatic features. 
Discussed analysis proves that the intuitively formulated idea which appeared nearly 100 years ago was based on correct assumptions which are still valid. Hence, location of new development in the infiltration corridors should be allowed only under careful analysis and strict conditions. One of those conditions is request to prepare aerodynamic analysis if the development is of a volume that might change the main conditions - i.e. large mall areas. Also, all newly built housing complexes should fulfil the "airing" conditions.

Admittedly, it is possible to include the views of the city anemology specialists within urban planning, with the exception of the condition that first of all, wide transport routes should take over the function of aeration corridors. However, it should be remembered that the climate issues are related to the issues of managing natural systems and entire land development structures. This view is therefore too simplistic and should be studied yet once more in detail

In order to mitigate the effects of weather extremes and climate, create clean air areas, reduce carbon dioxide and in general - neutralize, decompose and accumulate pollutants, it is necessary to shape comprehensive, sustainable structures of cities, involving green infrastructure. That is why the natural systems of cities are so important, as outlined in the previous subsection.

Focusing on the problems of urban air infiltration, however, requires emphasizing the conditions that should be taken into account when planning. The level and direction of prevailing winds characteristic to analysed areas significantly affects the quality of life of the residents - discomfort is caused both by exposure to strong winds, giving the impression of a continuous draft, whereas - such as lack of aeration, lowers the air quality. In order to ensure good air conditions for the city, it is necessary to eliminate local high-speed zones, and also - to plan such urban structures so that the air can freely "pass" through the city zone. It is important, however, that it is clean air, and this is difficult in cities with suburbs and suburban zones often built-up polluting industrial infrastructure. This is one of the principles of shaping compact cities, where there is a tendency to leave undeveloped external city areas.

The concept of aerating a city can have its positive and negative effects (with incorrect planning). On the one hand, it is possible to clean the city of pollution (as long as clean air can flow in and out), on the other hand - it is dispersed into other areas. This is why it is so important to integrate urban and extra-urban green systems in accordance with the prevailing wind directions and the development of research on the aerodynamics of the city in connection with other aspects of the city's ecology. It should also be noted that although the concept of aeration corridors (wedges), for the above-mentioned reasons, is now often criticized, the idea of air exchange in cities can be successfully used. However, it requires the construction of natural systems that would control the movement of air within the city, not forcing the inflow from outside. This approach appears to be more realistic with the use of contemporary software tools.

\section{REFERENCES}

[1] Europe 2020: A European strategy for smart, sustainable and iclusive growth. Communication from the Commission Brussels 03.03.2010.

[2] Territorial Agenda of the European Union 2020. Towards an Inclusive, Smart and Sustainable Europe of Diverse Regions. Agreed to at the Informal Ministerial Meeting of Ministers responsible for Spatial Planning and Territorial Development on 19th May 2011, Godollo, Hungary.

[3] Żmudzka, K., Nelken, K.., Leziak, A., Magnuszewski, A. \& Lenartowicz, M., Preparation of a strategy of adaptation to climate with the use of the city climate 
mapping and public participation, LIFE13 INF/PL/000039 LIFE ADAPTCITY PL, financed by LIFE and EU, 2016.

[4] KLIMADA, Adaptation to climate changes, www.klimada.mos.gov.pl. Accessed on: 04 Apr. 2018.

[5] ADAPTCITY (2014-2018), Preparation of an adaptation strategy for the climatic changes in metropolitan city, with the use of climate map and social participation. Project financed by LIFE and EU Commission. www.adaptcity.pl. Accessed on: 4 Apr. 2018.

[6] Ostrowski, W., Wprowadzenie do Historii Budowy Miast. Ludzie i Środowisko, Oficyna Wydawnicza Politechniki Warszawskiej: Warszawa, 1996.

[7] Sennett, R., Ciało i kamień. Człowiek i Miasto w Cywilizacji Zachodu, Wydawnictwo Marabut: Gdańsk, p. 206, 1996.

[8] Brown, L.J., Dixon, D. \& Gillham, O., Urban Design for An Urban Century, John Wiley \& Sons, Inc.: Hoboken, New Jersey, 2009.

[9] Kononowicz, W., Faces of Modernism in European Urban Planning of the First Three Decades of the 20th Century - Example of Wrocław, Modernism in Europe Modernism in Gdynia, Architecture in 1920s and in 1930s and its Protection, Gdynia City-Hall: Gdynia, pp. 13-20, 2009.

[10] Czyżewski, A., Trzewia Lewiatana. Miasta Ogrody i Narodziny Przedmieścia Kulturalnego, Państwowe Muzeum Etnograficzne w Warszawie: Warszawa, 2009.

[11] Kotaszewicz, T., Rozwój Urbanistyki i Planowania Przestrzennego Lat 1916-1945 z Podkreśleniem Roli Środowiska Warszawskiego, Osiagnięcia i Perspektywy Warszawskiego Środowiska Urbanistów i Planistów Przestrzennych, Oddział Warszawski TUP, Warszawa, pp. 27-45, 2002.

[12] Różański, S., Plan ogólny zabudowania m.st. Warszawy, Kronika Warszawy, Nr 12, VI, Warszawa, 1930.

[13] Kotarbiński, A., 1979, Jan Chmielewski - Sylwetka Twórcy i Zarys Działalności, Kwartalnik Architektury i Urbanistyki, PAN: Warszawa, pp. 13-72, 1979.

[14] Knapp, Z., Aglomeracja Warszawska. Ocena Studiów i Projektów Rozwoju Przestrzennego, Wydawnictwo Naukowe PWN: Warszawa-Łódź, 1986.

[15] Chmielewski J. M., Atlas Historyczny Warszawy. Plany Zagospodarowania Przestrzennego z Lat 1919-2002, Stowarzyszenie Przyjaciół Archiwum Państwowego m.st. Warszawy: Warszawa, 2004.

[16] Solarek, K., Cechy przestrzenne polskiej suburbanizacji - aglomeracja Warszawy a wybrane aglomeracje europejskie, ed. Nowak J., Gra o przestrzeń, BIULETYN KPZK PAN, Komitet Przestrzennego Zagospodarowania Kraju Polskiej Akademii Nauk, 265, pp. 36-64, 2017.

[17] Zalupka, M., ed., Shaping potential of climatic conditions - including air exchange and regeneration in the Warsaw City. Phase 2 Analysis prepared for the City of Warsaw by a consortium: Atmoterm SA, Atmoterm Environmental Engineering Ltd., Warsaw University of Technology, Urban Planning Team Kanon, 2017.

[18] Buckiewiczówna, M., Kwestia mieszkaniowa, Architektura i Budownictwo. Plany regulacyjne Warszawy starej i nowej, IV, z. 11, Warszawa, 1928.

[19] Schematic map of Warsaw air corridors:https://demotywatory.pl/4731527/Smog-towina-deweloperow-i-nowych-warszawiakow. Accessed on: 2 May 2018. 